\title{
Penerapan Metode Forward Chaining Pada Sistem Pakar Untuk Diagnosa Hama dan Penyakit Padi
}

\author{
${ }^{1}$ Khurotul Aeni \\ ${ }^{1}$ Teknik Informatika, Universitas Peradaban \\ ${ }^{1}$ Brebes, Indonesia \\ ${ }^{1}$ E-mail: khaeni988@peradaban.ac.id
}

\begin{abstract}
Abstrak-Agar komputer bisa bertindak seperti dan sebaik manusia, maka komputer harus diberi bekal pengetahuan yang mempunyai kemampuan untuk menalar. Salah satunya adalah sistem pakar, merupakan sistem yang berusaha mengadopsi pengetahuan manusia ke komputer yang dirancang untuk memodelkan kemampuan menyelesaikan masalah seperti layaknya seorang pakar. Dengan sistem pakar ini, orang awampun dapat menyelesaikan masalahnya atau hanya sekedar mencari suatu informasi yang sebenarnya hanya dapat diperoleh dengan bantuan para ahli dibidangnya. Pengetahuan masyarakat di Indonesia tentang hama dan penyakit tanaman padi masih rendah, termasuk penanganannnya hanya diketahui sebatas pengetahuan sesama petani, jika ada hama dan penyakit jenis baru petani tidak mengetahuinya, disisi lain terdapat beberapa ahli atau pakar yang banyak yang mengetahui tentang hama dan penyakit tanaman padi, akan tetapi jumlahnya ahli atau pakar dengan banyaknya jumlah petani tidak seimbang. Oleh karena itu, dengan adanya penerapan metode inferensi forward chaining pada sistem pakar untuk diagnosa hama dan penyakit tanaman padi dapat menjadi informasi dan pengetahuan yang akan membantu masyarakat ataupun perorangan untuk mengetahui jenis hama dan penyakita apa yang menyerang tanaman padinya, tanpa harus menunggu dan mengharapkan jawaban langsung dari ahlinya.
\end{abstract}

Kata Kunci- Sistem Pakar, Forward Chaining, Hama dan Penyakit Padi

Abstract-So that the computer can act as and as good as a human being, then the computer should be given the lack of knowledge that has the ability to catch. One of them is an expert system, is a system that attempted to adopt human knowledge to a computer that is designed to model the ability to resolve problems such as befits an expert. With this expert system, people who have yet to figure it out at all to resolve the problem or just simply looking for an actual information can only be obtained with the help of experts in their field.Knowledge society in Indonesia about pests and diseases of rice plant is still low, including handling is known only to the extent of the knowledge of fellow farmers, pest and disease if there is a new kind of farmers are not aware of it, on the other hand there are some the expert or experts who know about the pests and diseases of rice plant, but the number of experts or experts with a large number of farmers are not balanced. Therefore, due to the application of the method of forward chaining inference on expert system to diagnose plant pests and diseases of rice can be the information and knowledge that will help the community or individuals to know the types of pests and what diseases that attack the rice plant, without having to wait and expect a straight answer from the experts.

Keywords-Expert System, Forward Chaining, Pests And Diseases Of Rice 
INTENSIF, Vol.2 No.1 February 2018

ISSN: 2580-409X (Print) / 2549-6824 (Online)

http://ojs.unpkediri.ac.id/index.php/intensif

\section{PENDAHULUAN}

Tanaman padi adalah salah satu tanaman budidaya terpenting untuk kelangsungan hidup manusia. Padi menghasilkan beras yang merupakan makanan pokok bangsa Indonesia, sehingga tanaman tersebut menjadi salah satu bidang pertanian yang digalakkan dan hampir disetiap wilayah Indonesia. Kegiatan mencocok tanam tanaman padi menjadi suatu mata pencaharian sebagian besar warga tersebut, sehingga tingkat keberhasilan jumlah padi yang dipanenpun menjadi sangat penting karena mereka menggantungkan hidupnya dari beberapa besar padi yang dapat dipanen.[1]

Menurut harahap dan Tjahjono [2], pengetahuan masyarakat Indonesia tentang hama dan penyakit tanaman padi masih cukup rendah, termasuk penangananya. Serangan hama, tikus sawah, dan berbagai penyakit tanaman padi belum dapat dikendalikan secara sempurna, ketergantungan petani terhadap pestisida masih sangat tinggi. Kesalahan pemberian pestisida yang sering terjadi justru bukan karena kesalahan diagnosa, melainkan lebih sering dikarenakan kurang diperhatikannya penyakit dan cara pemakaian pestisida yang tidak disesuaikan dengan hama dan penyakit yang menyerang tanaman padi.

[3] Untuk saat ini pengetahuan petani tentang hama dan penyakit tanaman padi hanya diketahui sebatas pengetahuan sesama petani, jika ada hama dan penyakit jenis baru petani tidak mengetahuinya, disisi lain terdapat beberapa ahli atau pakar yang banyak mengetahui tentang hama dan penyakit tanaman padi, akan tetapi dengan jumlahnya ahli atau pakar dengan banyaknya jumlahnya petani tidak seimbang, sehingga ahli atau pakar tersebut tidak bisa menginformasikan tentang hama dan penyakit tanaman padi yang baru ataupun jenis hama dan penyakit yang lama, dikarenakan keterbatasan tenaga ahli atau pakar dan waktu dari seorang ahli atau pakar tersebut. Oleh karena itu, dengan adanya penerapan metode inferensi forward chaining pada sistem pakar untuk diagnosa hama dan penyakit tanaman padi, dapat menjadi informasi dan pengetahuan yang akan membantu masyarakat ataupun perorangan (petani) untuk mengetahui jenis hama dan penyakit apa yang menyerang tanaman padinya, tanpa harus menunggu dan mengharapkan jawaban langsung dari ahli atau pakarnya.

\section{Sistem Pakar}

Ada beberapa definisi tentang sistem pakar, diantaranya :

a. Sistem pakar sebagai “... suatu program komputer cerdas yang menggunakan pengetahuan dan prosedur inferensi untuk menyelesaikan maslah yang cukup sulit, sehingga membutuhkan seorang yang ahli untuk menyelesaikannya".[4] 
INTENSIF, Vol.2 No.1 February 2018 ISSN: 2580-409X (Print) / 2549-6824 (Online) http://ojs.unpkediri.ac.id/index.php/intensif

b. menurut Giarratano dan Riley : Sistem pakar adalah suatu sistem komputer yang bisa menyamai atau meniru kemampuan seorang pakar.[3]

Gambar 1. Menggambarkan konsep dasar suatu sistem pakar knowledge-base. Pengguna menyamakan fakta atau informasi untuk sistem pakar dan kemudian menerima saran dari pakar atau jawaban ahlinya. Bagian dalam sistem pakar terdiri dari 2 komponen utama, yaitu knowledge-base yang berisi knoledge dan mesin inferensi yang menggambarkan kesimpulan. Kesimpulan tersebut merupakan respons dari sistem pakar atas permintaan pengguna..

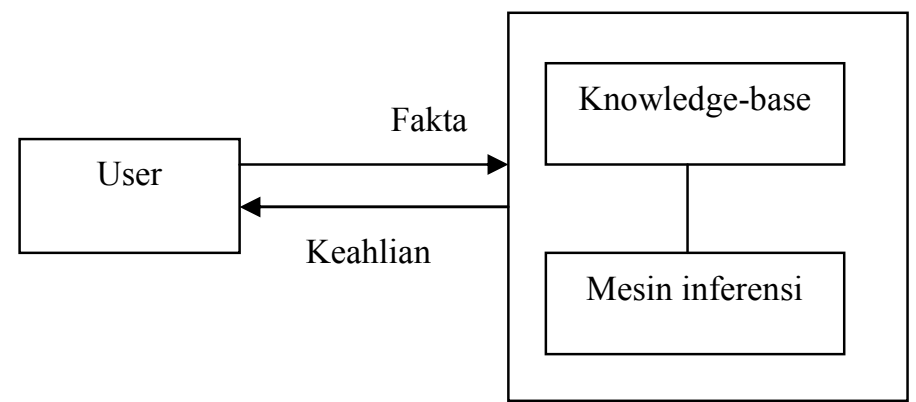

Gambar 1. KONSEP DASAR FUNGSI SISTEM PAKAR

\section{METODE PENELITIAN}

\section{A. Metode Pengumpulan Data}

1. Wawancara

2. Studi Pustaka

3. observasi

\section{B. Metode Pengembangan Sistem}

Metode pengembangan sistem dari penelitian ini menggunakan metode waterfall. Menurut Somerville, metode waterfall adalah metode yang menyarankan sebuah pendekatan yang sistematis dan sekuensial melalui tahapan-tahapan yang ada pada SDLC untuk membangun sebuah perangkat lunak.[5] 
INTENSIF, Vol.2 No.1 February 2018

ISSN: 2580-409X (Print) / 2549-6824 (Online)

http://ojs.unpkediri.ac.id/index.php/intensif

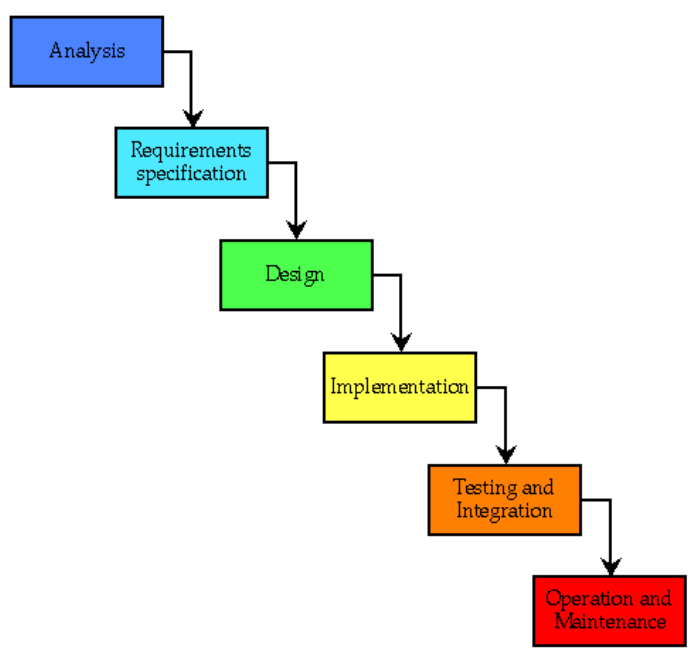

Gambar 2. TAHAPAN METODE SDLC

\section{Analisis Kelayakan Sistem}

Analisis kelayakan merupakan proses yang mempelajari atau menganalisa permasalahan yang telah ditentukan sesuai dengan tujuan akhir yang ingin dicapai. Tahapan ini berguna untuk memastikan solusi yang diusulkan tersebut benar-benar dapat tercapai dengan sumber daya dan dengan memperhatikan kendala yang terdapat pada permaslahan serta dampak lingkungan sekeliling. Analisis kelayakan sistem ini digunakan untuk mempelajari apakah usulan-usulan kebutuhan sistem baru layan untuk diterapkan. Ada lima macam kelayakan sistem dalam merancang sebuah sistem, diantaranya adalah kelayakan teknik, kelayakan operasional, kelayankan ekonomi, kelayakan jadwal, dan kelayakan hukum.

\section{Alur Kinerja Program}


INTENSIF, Vol.2 No.1 February 2018

ISSN: 2580-409X (Print) / 2549-6824 (Online)

http://ojs.unpkediri.ac.id/index.php/intensif

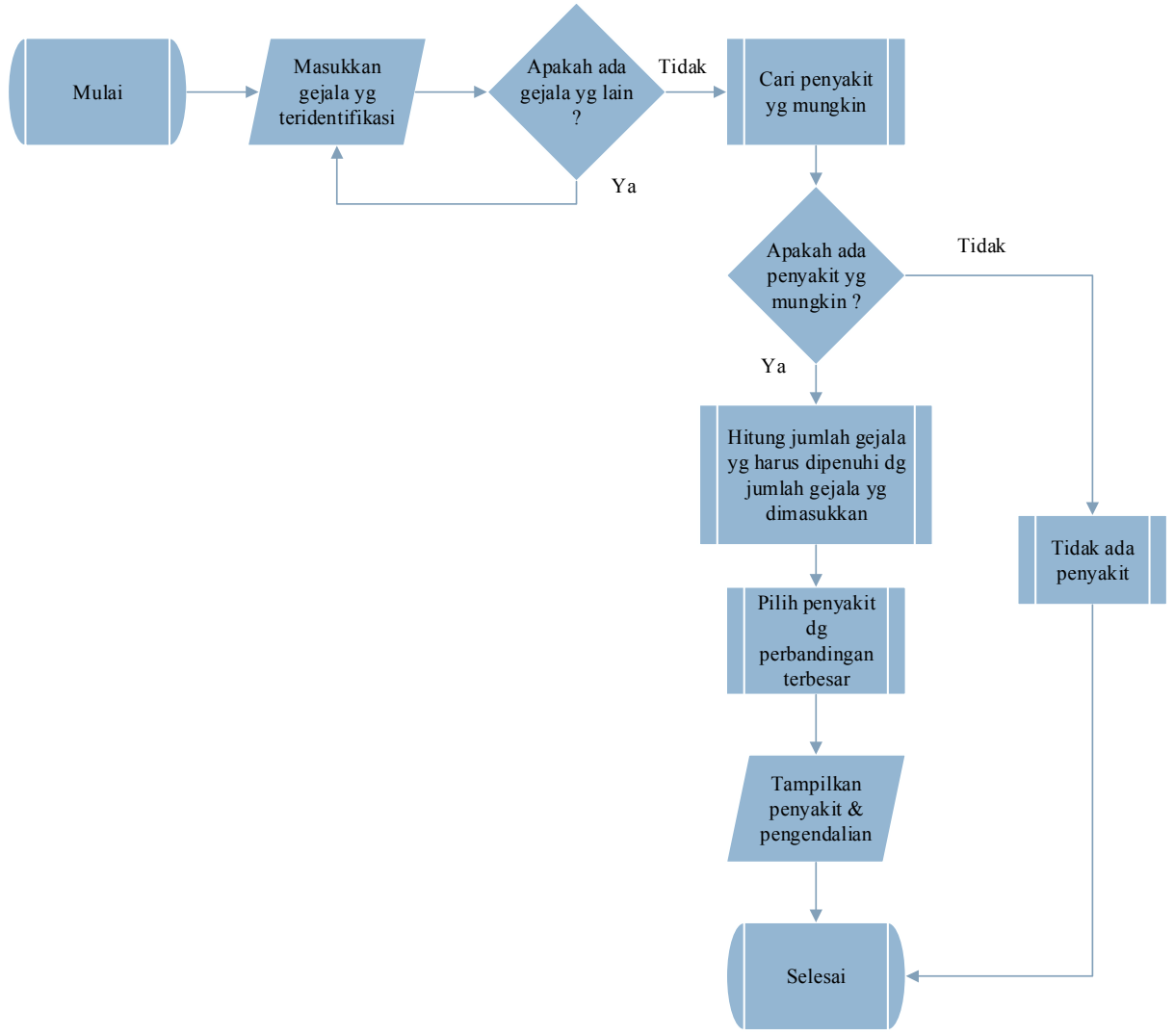

Gambar 3. FLOWCHART ALUR KINERJA PROGRAM/ SISTEM

\section{III.HASIL DAN PEMBAHASAN}

\section{A.Mengidentifikasi Masalah}

Hama dan penyakit tanaman padi merupakan faktor utama penyebab rendahnya produktivitas tanaman yang dalam kondisi tertentu dapat menyebabkan kegagalan pada suatu siste pertanian. Banyak kerugian yang diakibatkan karena adanya hama dan penyakit tanaman padi yang terlambat untuk didiagnosis. Ada sebagian petani yang tidak mengetahui jenis penyakit yang menyerang tanaman padinya, sehingga penanganannya dilakukan seadanya dan tidak sesuai prosedur yang seharusnya. Permasalahan diagnosa hama dan penyakit tanaman padi dapat dilakukan pemecahan masalah dengan membuat dan mengembangkan sistem yang dapat berperan sebagai seorang ahli atau pakar hama dan penyakit tanaman padi. Dengan kata lain terjadi pemindahan atau proses pengolahan informasi yang bersifat heuristik (khusus), yang artinya membangun mengoperasikan basis pengetahuan dari seorang pakar ke sebuah sistem komputer. 
INTENSIF, Vol.2 No.1 February 2018

ISSN: 2580-409X (Print) / 2549-6824 (Online)

http://ojs.unpkediri.ac.id/index.php/intensif

\section{B. Diagram Konteks}

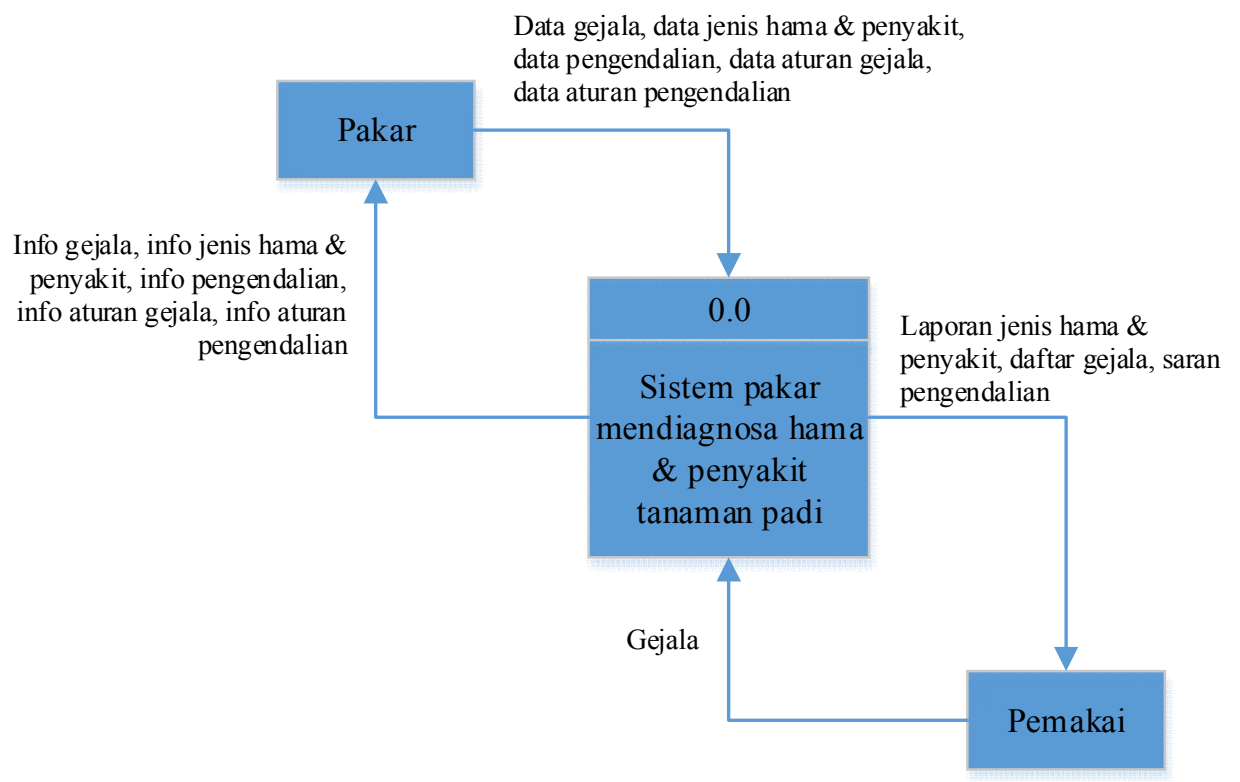

Gambar 4. DIAGRAM KONTEKS

\section{Basis Pengetahuan dan Basis Aturan}

Tabel 1. ATURAN Gejala

\begin{tabular}{ll}
\hline \hline No & \multicolumn{1}{c}{ Aturan } \\
\hline 1 & IF menyerang bulir padi pada fase pemasakan AND terdapat bekas isapan pada daun \\
& AND bulir padi menjadi hampa AND bulir tampak berwarna kecoklatan AND bulir \\
& tidak enak dan bau AND beras berubah warna dan mengapur THEN Hama Walang \\
& Sangit \\
\hline 2 & $\begin{array}{l}\text { IF tunas padi yang tumbuh menjadi bentuk seperti pentil atau daun bawang AND } \\
\text { jumlah tunas menjadi lebih banykak tapi tidak bermalai AND warna tanaman agak } \\
\text { kekuningan THEN Hama Ganjur }\end{array}$ \\
\hline
\end{tabular}

Pembentukan aturan jenis hama dan penyakit padi situnjukkan pada tabel 2 berikut ini

Tabel 2. ATURAN JENIS HAMA DAN PENYAKIT

\begin{tabular}{lcl}
\hline \hline No & Penyakit & \multicolumn{1}{c}{ Deskripsi } \\
\hline 1 & Hama Walang & $\begin{array}{l}\text { Walang Sangit merupakan hama yang umum merusak bulir padi } \\
\text { pada fase pemasakan. Mekanisme merusaknya yaitu menghisap } \\
\text { butiran gabah yang sedang mengisi. Apabila diganggu, serangga } \\
\end{array}$ \\
& akan mempertahankan diri dengan mengeluarkan bau \\
\hline 2 & Hama Ganjur & $\begin{array}{l}\text { Umumnya bukan merupakan hama utama padi di Indonesia. } \\
\end{array}$ \\
& $\begin{array}{l}\text { Hama ini hanya sedikit merugikan, sangat bersifat lokal, dan } \\
\text { hanya terjadi pada musim tertentu saja. Namun demikian, } \\
\end{array}$ & serangan ganjur dapat terjadi sejak pertanaman masih pembibitan \\
& sampai tanaman mencapai fase primordia \\
\hline
\end{tabular}


INTENSIF, Vol.2 No.1 February 2018

ISSN: 2580-409X (Print) / 2549-6824 (Online)

http://ojs.unpkediri.ac.id/index.php/intensif

\section{Metode Mesin Inferensi/ Mekanisme Inferensi}

Selama proses konsultasi, mesin inferensi yang digunakan adalah inferensi forward chaining, dimana dilakukan pengujian fakta-fakta yang dimasukkan pemakai, fakta-fakta tersebut adalah gejala-gejala dari serangan hama dan penyakit tanaman padi, dengan aturan yang telah disimpan dalam sistem, satu demi satu hingga dapat diambil satu keputusan/ kesimpulan. Berikut ini adalah graf penelusuran dan pelacakan menggunakan inferensi forward chaining.

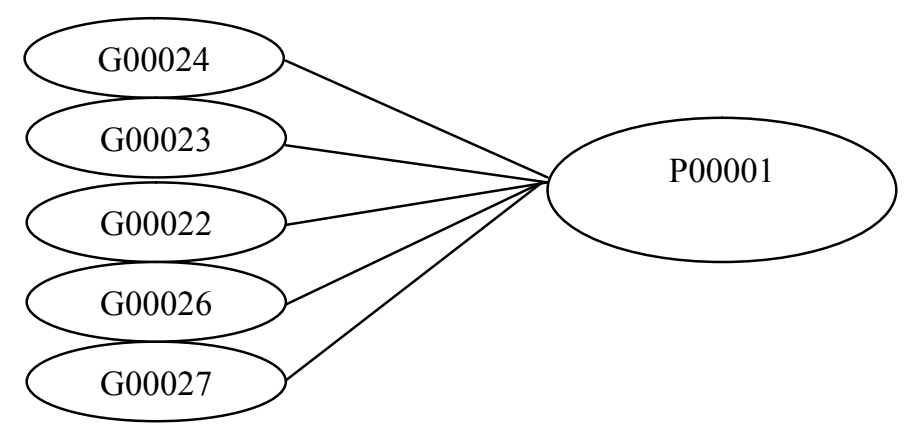

\section{Gambar 5. GRAF PENELUSURAN HAMA WALANG SANGIT}

Pada graf diatas terdapat gejala-gejala yaitu, apabila diganggu serangga akan mempertahankan diri dengan bau (G00024), mekanisme merusaknya yaitu menghisap butiran gabah yang sedang mengisi (G200023), merusak bulir pada fase pemasakan (G00022), kerusakan yang ditimbulkan menyebabkan beras berubah warna dan mengapur (G00026), gabah menjadi hampa (G00027), maka penyakit yang menyerang tanaman padi adalah Hama Walang Sangit.

\section{E. Rancangan Antarmuka}

Menu Hama \& Penyakit

Form data penyakit berfungsi untuk melakukan pengolahan data-data hama dan penyakit. Form ini diisi oleh seorang pakar atau pengembang sistem.

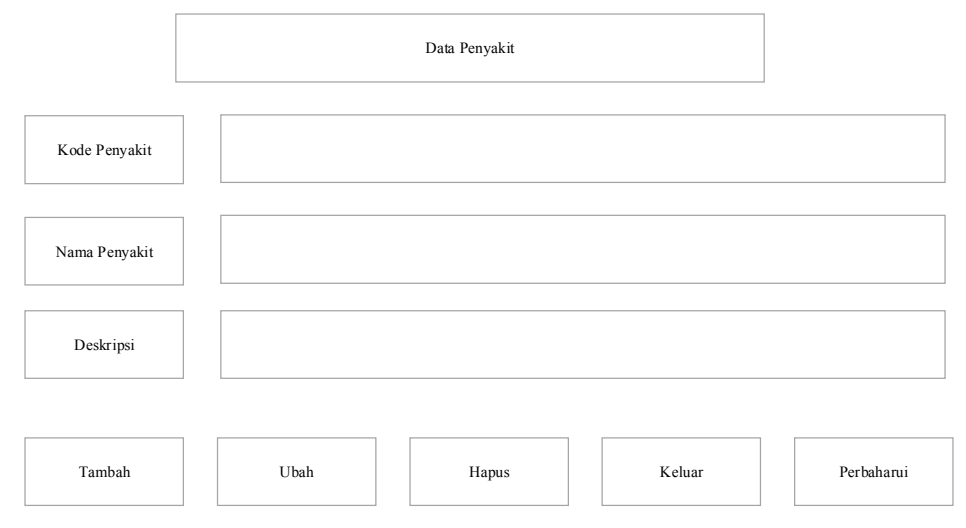

Gambar 6. RANCANGAN ANTARMUKA PROGRAM/ SISTEM 
INTENSIF, Vol.2 No.1 February 2018

ISSN: 2580-409X (Print) / 2549-6824 (Online)

http://ojs.unpkediri.ac.id/index.php/intensif

\section{IV.KESIMPULAN DAN SARAN}

Aplikasi sistemm pakar menggunakan metode inferensi forward chaining telah dibuat untuk mendiagnosa hama dan penyakit tanaman padi, sehingga dapat memberikan informasi kepada pemakai khususnya petani mengenai jenis hama dan penyakit, gejala-gejala serangan berdasarkan pertanyaan-pertanyaan yang telah diajukan ahli atau pakar kepada pemakai, serta memberikan informasi pengendaliannya. Untuk mendapatkan hasil yang maksimal dan menarik, maka program aplikasi ini dapat pula dilengkapi dengan fasilitas multimedia (suara dan gambar), Program aplikasi ini diharapkan untuk pengembangan selanjutnya dapat di tambahkan berbasis web, Dikarenakan ilmu pengetahuan yang terus berkembang dan ditemukan hal-hal yang baru dalam pertanian, maka basis pengetahuan dan basis aturan sistem pakar ini perlu diperbaharui atau ditambahkan, sehingga data-data yang ada menjadi lebih lengkap, kompleks, dan akurat.

\section{DAFTAR PUSTAKA}

[1] A. H. Dadi Rosadi, "Sistem Pakar Diagnosa Penyakit Tanaman Padi Menggunakan Metode Forward Chaining," Jurnal Computech \& Bisnis, Vol-8, No.1, 2014.

[2] B. Tjahjono, Pengendalian Hama dan Penyakit Padi, Jakarta, 2003.

[3] S. Kusumadewi, Artificial Intelligence (Teknik dan Aplikasinya), Yogyakarta: Graha Ilmu, 2003.

[4] M. Arhami, Konsep Dasar Sistem Pakar, Yogyakarta: Andi, 2005.

[5] I. Sommerville, Software Engineering (Rekayasa Perangkat Lunak), Jakarta: Erlangga, 2011. 